\title{
Fitokimia Dan Aktivitas Antibakteri Dari Daun KAF(Chisocheton sp. (C. DC) HARMS)
}

Florentin N. Melsadalama ${ }^{*}$, Dewa G, Katjaa, Meiske S. Sangia

aJurusanKimia, FMIPA, Unsrat, Manado

\begin{tabular}{l}
\hline K A T A K U N C I \\
\hline Daun Kaf, Fitokimia, \\
Antibakteri
\end{tabular}

A B S T R A K

Telah dilakukan penelitian yang bertujuan untuk mengidentifikasi senyawa metabolit sekunder dari ekstrak daun kaf menggunakan tiga jenis pelarut yakni $n$-heksan, etil asetat, dan metanol. Ekstrak yang diperoleh diuji aktivitas antibakterinya dengan metode difusi yang menggunakan bakteri Staphylococcusaureus dan Escherichia coli. Dari hasil pengujian fitokimia, ketiga ekstrak tersebut menunjukan bahwa sampel mengandung senyawa; alkaloid, saponin, steroid, flavonoid dan tanin. Pengujian aktivitas antibakteri dengan metode difusi menunjukan hasil yang paling tinggi aktivitas antibakteri adalah estrak etil asetat dengan zona hambat 35,75 mm terhadap bakteri Staphylococcus aureus, sedangkan pada ekstrak metanol memiliki zona hambat $23,75 \mathrm{~mm}$ terhadap bakteri Escherichia coli.

\begin{tabular}{l}
\hline K E Y W O R D S \\
\hline Leave kaf, phytochemical, \\
antibacterials
\end{tabular}
antibacterials

A B S T R A C T
Research has been carried out aimed at identifying secondary
metabolites of kaf leaf extract using three types of solvents, namely $\mathrm{n}$ -
hexane, ethyl acetate, and methanol.The obtained extracts were tested for
antibacterial activity by diffusion method using Staphylococcus aureus and
Escherichia coli bacteria. From the results of phytochemical testing, the
three extracts showed that the sample contained compounds; alkaloids,
saponins, steroids, flavonoids and tannins. Antibacterial activity testing
with diffusion method showed the highest antibacterial activity was
estracethyl ethyl acetate with 35.75 mm inhibition zone against
Staphylococcus aureus bacteria, whereas methanol had 23.75 mm
inhibitory zone against Escherichia coli bacteria.

TERSEDIA ONLINE

01 Agustus 2019

1. Pendahuluan

Indonesia merupakan negara yang kaya akan sumber tanaman obat yang secara turuntemuruntelah digunakan sebagai ramuan obat tradisional. Masyarakat sekarang lebih memilih untuk bahan alami walaupun perkembangan ilmu pengetahuan dan teknologi semakin moderen. Penggunaan obat tradisional menjadi pilihan utama karena efek samping obat tradisional yang relatif kecil jika digunakan secara tepat dan tanpa penyalahgunaan (Krisyanella, 2009).

Tumbuhan kaf merupakan salah satu famili meliaceae dengan genus chisocheton. Genus Chisochetontelah banyak dilaporkan dan menghasilkan senyawa aktif yang bersifat antikanker, sitotoksik, antitumor, antiinflamasi, antimalaria, antimikroba, dan antilipid (Wong et al., Awang et al., 2012; Najmuldeen et al., 2012).

Analisis fitokimia dilakukan untuk menentukan ciri komponen bioaktif suatu ekstrak kasar yang mempunyai efek racun atau efek farmakologis lain yang bermanfaat bila diujikan dengan sistem biologi atau bioassay (Harbone, 1987).

Beberapa bakteri telah mengalami resistensi dengan antibiotic tertentu, oleh karena alternative pengobatan yang berasal dari alam menjadi semakin nyata. Bakteri pathogen lebih berbahaya dan menyebabkan infeksi baik secara sporadik maupun endemik, antara lain bakteristaphylococcus aureus \& escherichia coli (Djide dan Sartini, 2008).

Berdasarkan penelusuran jurnal belum ada literatur yang meneliti tumbuhan kaf, tumbuhan kaf belum di ketahui kandungan fitokimia dan aktivitas antibakteri, oleh karena itu akan dilakukan
2011; Mohamadet al., 2008; Yang et al., 2009; 
penelitian tentang analisis kandungan fitokimia dan aktivitas anti bakteri dari daun kaf dengan mengunakan metode difusi sumuran.

\section{Material dan Metode Alat dan Bahan}

Alat yang digunakan gelas kimia, gelas ukur, botol vial, labu ukur, alumunium voil, spatula, corong kaca, Kertas Whatman no 42, rotary vacuum evaporator,seperangkat alat distilasi, penangas listrik, cawan porselin, oven, pisau, ayakan 65 mesh dan blender, kaca arloji, timbangan analitik, batang pengaduk, stirer, cawan petri, jarum ose, pinset, inkubator,laminair air flow, termometer, pencadang, autoklaf, mikropipet, mistar berskala dan alat fotografi.

Bahan yang digunakan yaitu serbuk dari daun kaf (Hutan Tidore), metanol (redestilasi), n-heksan (redestilasi), etilasetat (redestilasi), akuades, bakteri uji (Staphylococcus aureusATCC 25923dan Escherichia coliATCC 25922), Nutrient Agar (NA), DMSO (Dimethyl sulfoxide) (Merck $®)$, yang diperoleh dari Laboratorium Mikrobiologi Balai Besar POM Manado, tablet Ciprofloxacin $500 \mathrm{mg}, \mathrm{H}_{2} \mathrm{SO}_{4}$ 0,36 N, $\mathrm{BaCl}_{2} .2 \mathrm{H}_{2} \mathrm{O}$ 1,175\%, $\mathrm{NaCl} 0,9 \%$.

\section{Preparasi Sampel}

Sampel daun tumbuhan kaf yang diperoleh terlebih dahulu dibersihkan dari kotoran yang menempel dan dikering-anginkan selama 5 hari sampai daun kering, selanjutnya diblender dan di ayak dengan ayakan 65 mesh sehingga seruk halus dan diperoleh serbuk daun kaf yang siap untuk dimaserasi sebanyak $1000 \mathrm{~g}$.

\section{Kadar Air (AOAC, 1995)}

Sebanyak 2 gram serbuk ditimbang secara teliti dalam cawan porselin yang telah dikeringkan dan diketahui bobotnya. Cawan kemudian dikeringkan dalam oven pada suhu $105-110^{\circ} \mathrm{C}$ selama tiga jam. Cawan dikeluarkan dan didinginkan dalam desikator, kemudian ditimbang. Pengeringan dilanjutkan lagi dan setiap setengah jam didinginkan dan ditimbang sampai diperoleh bobot yang konstan.

\section{Ekstraksi Daun Kaf}

Sebanyak 200 gram serbuk daun kaf dimaserasi dengan pelarut metanol, n-heksan, dan etilasetat masing-masing sebanyak $2000 \mathrm{~mL}$. Maserasi dilakukanselama 3 x 24 jam. Hasil maserasi disaring menggunakan kertas saringWhatman no 42 dan filtrat yang diperoleh diuapkan secara vakum menggunakan penguap putar rotary vacuum evaporator untuk memperoleh ekstrak kental.

\section{Uji Fitokimia Daun Kaf (Harborne, 1996)}

Uji fitokimia pada ektrak metanol, etilasetat dan n-heksan dari daun kaf meliputi pemeriksaan alkoloid, steroid, tritepernoid, flavonoid, saponin dan tannin dengan langkah sebagai berikut.

\section{Pembuatan Larutan Uji Fitokimia}

Pembuatan larutan uji untuk skrining fitokimia dilakukan dengan melarutkan 500 mg ekstrak kental metanol dalam $50 \mathrm{~mL}$ metanol, dilakukan perlakuan yang sama pada ekstrak kental etil asetat dan ekstrak kental n-heksan.

\section{Identifikasi Kandungan Alkaloid}

Sebanyak $2 \mathrm{~mL}$ larutan uji dari masing-masing ekstrak dimasukkan dalam tabung reaksi dan ditambah dengan 5 tetes amonia pekat. Setelah itu, disaring kemudian ditambah $2 \mathrm{~mL} \mathrm{H}_{2} \mathrm{SO}_{4} 2 \mathrm{~N}$ dan dikocok hingga memberi lapisan atas dan bawah. Lapisan dibawah diambil dan dipindahkan kedalam 3 tabung reaksi, pada tabung pertama ditambahkan 1 tetes Mayer, adanya alkaloid ditandai dengan terbentuknya endapan putih. Pada tabung kedua ditambah 1 tetes pereaksi Dragendorf dan terbentuknya endapan jingga menandakan adanya alkaloid. Tabung ketiga ditambah 1 tetes pereaksi Wagner dan terbentuknya endapan Coklat menandakan adanya alkaloid.

\section{Identifikasi Kandungan Steroid dan Triterpenoid}

Sebanyak $2 \mathrm{ml}$ larutan uji dari masing-masing ekstrakdimasukkan dalam tabung reaksi. Kemudian ditambah dengan asam asetat anhidrat 1 tetes dan asam sulfat pekat 2 tetes. Jika terbentuk warna biru atau hijau menandakan adanya steroid. Jika terbentuk warna ungu atau jingga menandakan adanya triterpenoid.

\section{Identifikasi Kandungan Flavonoid}

Sebanyak $2 \mathrm{ml}$ larutan uji dari masing-masing ekstrakdimasukkan dalam tabung reaksi. Kemudian ditambah dengan 5 tetes etanol, lalu dikocok sampai homogen. Setelah itu ditambah dengan serbuk $\mathrm{Mg} 0.2 \mathrm{gr}$ dan 5 tetes $\mathrm{HCl}$ pekat. Jika menghasilkan warna kuning, orange, dan merah menandakan adanya flavonoid.

\section{Identifikasi Kandungan Saponin}

Sebanyak $2 \mathrm{ml}$ larutan uji dari masing-masing ekstrakdimasukkan dalam tabung reaksi. Kemudian ditambah $2 \mathrm{ml}$ aquades, lalu dikocok sampai homogen. Setelah itu, dipanaskan selama 3 menit. Dinginkan, setelah dingin kocok dengankuat.Adanya busa yang stabil selama 30 detik menunjukkan sampel mengandung saponin.

\section{Identifikasi Kandungan Tanin}

Sebanyak 2 teteslarutan uji dari masing-masing ekstrakditeteskan padatabung reaksi. Kemudian ditambahkan dengan $\mathrm{FeCl}_{3}$ 10\% 3 tetes. Adanya tanin ditandai dengan terbentuknya warna biru tua atau hitam kehijauan.

\section{Uji Aktivitas Antibakteri}

Sterilisasi Alat(Lay dan Hastowo, 1992)

\footnotetext{
*Corresponding author: Jurusan Biologi FMIPA UNSRAT, Jl. Kampus Unsrat, Manado, Indonesia 95115; Email address: cysuchy@ymail.com

Published by FMIPA UNSRAT (2013)
} 


\begin{abstract}
Alat-alat yang digunakan dalam penelitianaktivitas antibakteri ini disterilkan terlebihdahulu. Alat-alat gelas disterilkan dalam oven pada suhu $170^{\circ} \mathrm{C}$ selama 2 jam, jarum osedan pinset dibakar dengan pembakaran diatasapi langsung dan media disterilkan dalam autoklaf pada suhu $121^{\circ} \mathrm{C}$ selama 15 menit.

Sebanyak 2 teteslarutan uji dari masing-masing ekstrakditeteskan padatabung reaksi.Kemudian ditambahkan dengan $\mathrm{FeCl}_{3} \quad 10 \% 3$ tetes.Adanya tanin ditandai dengan terbentuknya warna biru tua atau hitam kehijauan.
\end{abstract}

\section{Pembuatan Larutan Kontrol Positif (Lay,1994)}

Kontrol positif dibuat dari sediaan obat tablet Ciprofloxacin 500 mg. Satu tablet Ciprofloxacin digerus, lalu ditimbang dan disetarakan dengan 500 mg. Kemudian serbuk Ciprofloxacin dilarutkan dalam larutan aquades untuk memperoleh larutan Ciprofloxacin $50 \mu \mathrm{g} / 50 \mu \mathrm{l}$.

\section{Pembuatan Larutan Uji (Lay, 1994)}

Dibuat larutan uji $100 \% \mathrm{~b} / \mathrm{v}$ dengan cara ditimbang $0,8 \mathrm{~g}$ ekstrak heksan, etil asetat dan metanol daun kaf,dilarutkan kembali dengan pelarut masing-masing sebanyak $1 \mathrm{ml}$ kemudian dilarutkan dalam $1 \mathrm{ml}$ larutan aquades.

Pembuatan Standar Kekeruhan Larutan (Larutan Mc. Farland) (Victor,1980)

Larutan $\mathrm{H}_{2} \mathrm{SO}_{4} \quad 0,36 \quad \mathrm{~N}$ sebanyak 99,5 mldicampurkan dengan larutan $\mathrm{BaCl}_{2} \cdot 2 \mathrm{H}_{2} \mathrm{O} 1,175 \%$ sebanyak 0,5 ml dalam erlenmeyer. Kemudian dikocok sampai terbentuk larutan yang keruh. Kekeruhan ini dipakai sebagai standar kekeruhan suspensi bakteri uji.

Pembuatan Suspensi Bakteri Uji (Lay, 1994)

Bakteri uji yang telah diinokulasi diambildengan kawat ose steril lalu disuspensikankedalam tabung yang berisi $2 \mathrm{ml}$ larutan $\mathrm{NaClO}, 9 \%$ hingga di peroleh kekeruhan yang sama dengan standar kekeruhan larutan Mc. Farland. Perlakuan yang sama dilakukan padasetiap jenis bakteri uji.

Pembuatan Media Pengujian (Lay, 1994)

Lapisan dasar dibuat dengan

menuangkanmasing-masing 50ml NA dari media dasar kedalam 3 cawan petri, lalu dibiarkan sampai memadat. Setelah memadat, pada permukaan lapisan dasar diletakkan 5 pencadang baja yangdiatur sedemikian rupa jaraknya agar daerah pengamatan tidak saling bertumpuh. Kemudian, suspensi bakteri dicampurkan kedalam media pembenihan NA. Setelah itu, dituangkan $50 \mathrm{ml}$ campuran suspensi dan media pembenihan tersebut ke dalam tiap cawan petri yang diletakkan pencadang sebagai lapisan kedua. Selanjutnya, pencadang diangkat secara aseptik dari cawan petri, sehingga akhirnya terbentuklah sumur-sumur yang akan digunakan dalam uji antibakteri.

Uji Aktifitas Antibakteri secara In-vitro(Lay, 1994)

Uji Aktivitas Antibakteri secara In-vitro meggunakan metode Mpila et al.(2012), yang telah dimodifikasi. Larutan uji ekstrak N-Heksan, etil asetat dan metanol daun chisocheton dengan konsentrasi (100\%); larutan akuades $1 \%$ sebagai kontrol negatif; Iarutan Ciprofloxacin $50 \mu \mathrm{g} / 50 \mu \mathrm{l}$ sebagai kontrol positif, masing-masing diteteskan pada sumur yang berbeda sebanyak $50 \mu \mathrm{\mu l}$. Kemudian cawan petri diinkubasi dalam inkubator pada suhu $37^{\circ} \mathrm{C}$ selama $1 \times 24$ jam.

Pengamatan dan Pengukuran (Lay, 1994)

Pengamatan dilakukan setelah 1x24 jam masa inkubasi. Daerah bening merupakanpetunjuk kepekaan bakteri terhadap antibiotik atau bahan antibakteri lainnya yang digunakansebagai bahan uji yang dinyatakan dengan lebar diameter zona hambat (Vandepitte et al ,2005). Diameter zona hambat diukur dalam satuan milimeter $(\mathrm{mm})$ menggunakan mistar berskala dengan cara diameter keseluruhan dikurangi diameter sumuran $7 \mathrm{~mm}$. Kemudian diameter zona hambat tersebut dikategorikan kekuatan daya antibakterinya berdasarkan penggolongan Davis and Stout (1971).

\section{Hasil dan Pembahasan Kadar Air}

Tabel 1. Kadar air

\begin{tabular}{ccc}
\hline Pengujin ke- & Kadar Air(\%) & Rara-rata(\%) \\
\hline I & 7.54 & \\
II & 7.51 & 7.49 \\
III & 7.41 & \\
\hline
\end{tabular}

Kadar air dari serbuk daun kaf memiliki ratarata sebesar 7,49\%. Persentase kadar air yang rendah atau di bawah $10 \%$ dapat mengoptimalkan ketahanan bahan pangan dari serbuk daun kafdalam waktu yang relatif lama dan tidak mudah rusak.

\section{EKsraksi}

Tabel 2. Rendemen Hasil Maserasi

\begin{tabular}{ccc}
\hline Ekstrak & Rendemen (\%) & Warna \\
\hline$n$-Heksana & 6.285 & Hijau \\
Etil Asetat & 11,907 & $\begin{array}{c}\text { Hijau } \\
\text { kecoklatan }\end{array}$ \\
Metanol & 15.426 & Coklat \\
\hline
\end{tabular}

Pelarut metanol mampu menghasilkan rendemen tertinggi dibandingkan dengan pelarut etil asetat dan n-heksan.Tingginya rendemen ekstrak metanol disebabkan banyaknya jumlah senyawa polar yang terkandung dalam daun kaf tersebut. 


\section{Kandungan Fitokimia}

Tabel 3. Hasil Uji Fitokimia Ekstrak daun kaf dari ketiga pelarut

\begin{tabular}{|c|c|c|c|}
\hline \multirow{2}{*}{$\begin{array}{l}\text { Senyawa } \\
\text { Metabolit } \\
\text { Sekunder }\end{array}$} & \multicolumn{3}{|c|}{ Ekstrak } \\
\hline & $n$-heksane & $\begin{array}{c}\text { Etil } \\
\text { asetat }\end{array}$ & Metanol \\
\hline \multicolumn{4}{|l|}{ Alkaloid } \\
\hline Mayer & - & + & + \\
\hline Wagner & + & + & + \\
\hline Dragendorf & + & + & + \\
\hline Flavonoid & - & + & + \\
\hline Saponin & + & + & + \\
\hline Steroid & - & + & + \\
\hline Triterpenoid & - & - & - \\
\hline Tanin & - & + & + \\
\hline \multicolumn{4}{|c|}{$\begin{array}{l}\text { Komponen yang terdapat dalam ekstrak n- } \\
\text { heksan, etil asetat, dan metanol pada daun kaf } \\
\text { menunjukan bahwa skrining fitokimia terhadap } \\
\text { sampel ekstrak daun kaf menunjukan bahwa } \\
\text { sampel mengandung senyawa; alkaloid, saponin, } \\
\text { steroid, flavonoid dan tanin. }\end{array}$} \\
\hline
\end{tabular}

\section{Aktivitas Antibakteri}

Hasil dari uji aktivitas antibakteri dengan menggunakan metode difusi, dengan carasumuran agar hasil pengukuran rata-rata mendapatkan diameter zonahambat yang ada di ekstrak daun kaf terhadap bakteri Staphylococcus aureus dan Escherichiacoli dideskripsikan pada Gambar 1.

(a)

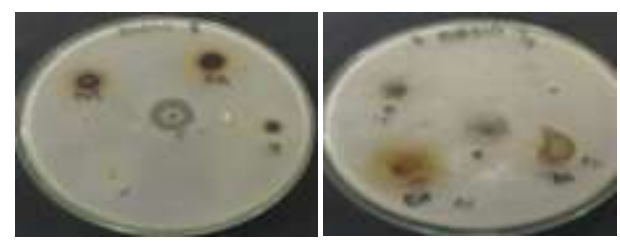

Gambar 1.(a) Staphylococcus aureus, (b) Escherichia coli Tabel 4.Hasil Pengukuran Rata - Rata Diameter Zona Hambat Eksrak n-Heksan, Etil Asetat, dan Methanol dari Daun Kaf (Chisocheton sp. (C.DC). Harms) Terhadap Pertumbuhan Bakteri Staphylococcus aureusdan Escherichiacoli, selama 1 jam.

\begin{tabular}{lcc}
\hline & \multicolumn{2}{c}{ Rata - Rata Diameter Zona } \\
Hambat \\
Konsentrasi & $\begin{array}{c}\text { Pertumbuhan Bakteri (mm) } \\
\text { S. aureus }\end{array}$ & E. coli \\
\hline $\mathrm{n}$ - Heksan & 21.75 & 12.83 \\
Etil Asetat & 35.25 & 22.83 \\
Metanol & 29 & 23.75 \\
kontrol $(+)$ & 34.75 & 33.5 \\
kontrol $(-)$ & 0 & 0 \\
\hline
\end{tabular}

Daya antibakteri dari ekstrak daun kaf (Chisocheton sp. (C.DC). Harms) dengan lama waktupencampuran 1 jam pada bakteri Staphylococcus aureus yang didapatkan pada sampel ekstrak n-heksan (21.75 mm), eksrak etil asetat (35.25 mm) mencapai kategori sangat kuat dan ekstrak metanol $(29 \mathrm{~mm})$ termasuk kuat.Sedangkan pada daya antibakteri Escherichia coli pada sampel eksrak n-heksan (12.83 mm), eksrak etil asetat (22.83) termasuk kuat, dan ekstrak metanol (23.75) dikategorikan sangat kuat.

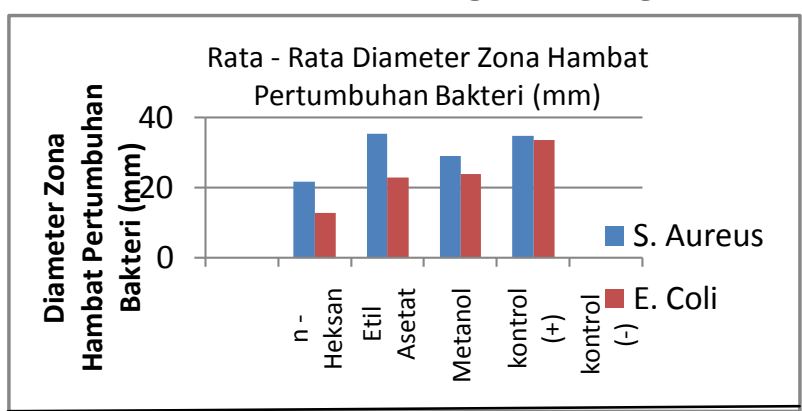

Gambar 2.Persentase Rata-rata Zana Hambat Pertumbuhan Bakteri

Dalam penelitian ini aktivitaseksrak n-heksan, etil asetat, dan metanol dari daun kaf (Chisocheton sp. (C.DC) Harms) dengan lama waktu pencampuran 1 jam dalam menghambatpertumbuhan bakteri gram positif Staphylococcus aureus lebih baik dibandingkan dengan bakteri gram negatif Escherichia coli. Dinding sel grampositif biasanya tidak memiliki membran sel bagian luar yang ditemukan pada bakteri gram negatif.

\section{Kesimpulan}

Dari hasil pengujian fitokimia, ketiga ekstrak tersebut menunjukan bahwa sampel mengandung senyawa; alkaloid, saponin, steroid, flavonoid dan tanin. Pengujian aktivitas antibakteri dengan metode difusi menunjukan hasil yang paling tinggi aktivitas antibakteri adalah estrak etil asetat dengan zona hambat $35,75 \mathrm{~mm}$ terhadap bakteri Staphylococcus aureus, sedangkan pada ekstrak metanol memiliki zona hambat 23,75 mm terhadap bakteri Escherichia coli.

\section{Daftar Pustaka}

AOAC. 1995. Offical Methods of Analysis 16 ${ }^{\text {th }}$ Ed. Association of Offical Analytical Chemist. Washington DC, USA.

Awang, K., Chong, L., Marthi, M.T., Mokhtar, R.M., Chan, G., Litaudon, M., Gueritte, F., and Mohamad, K. 2012. Malayanines A and B, two novel limonoids from Chisochetonerythrocarpus Hiern, Tetrahedron Letters, 53 : 5355-5359.

Davis, W.W \& Stout, T.R. 1971. Disc PlateMethods of Microbiological Antibiotic Assay. Microbiology. 22:659-665.

Djide dan Sartini. 2008. Dasar-Dasar Mikrobiologi Farmasi. Lephas, Makasar. 

Harborne, J.B. 1987. Metode Fitokimia: Penuntun Cara Modern Mengekstraksi Tumbuhan Ed $2^{\text {nd }}$, ITB, Bandung.

Harborne, J.B. 1996. Metode Fitokimia: Penuntun Cara Modern Menganalisis Tumbuhan. Terjemahan Kosasih Padmawinata dan Iwang Soediro, ITB, Bandung.

Krisyanella, D. Marlina. 2009. Karakterisasi Simplisia dan Ekstrak Serta Isolasi Senyawa Aktif Antibakteri dari Daun Karamunting (Rhodomyrtus tomentosa (W.Ait ) Hassk). Padang: Fakultas Farmasi Universitas Andalas.

Lay, B.W dan Hastowo, S. 1992.Mikrobiologi. Institut Pertanian Bogor, Bogor.

Lay, B.W. 1994. Analisis Mikroba diLaboratorium.Edisi 1. Raja Grafindo Persada, Jakarta.

Mohamad, K., Hirasawa, Y., Lim, C.S., Awang, K., Hamid, A., Hadi, A., Takeya, K., \& Morita, H. 2008. Ceramicines $A$ and walsogyne $A$, novel limonoids from two species of Meliaceae. Tetrahedron Letters, 49: 4276-4278.

Najmuldeen, I. A., Ibrahim, A., Tasyriq, M., Lionel, L. A. I., Mohamad, K., Awang, K., and Hasima, N. $2012.7 \alpha$-hidroxy- $\beta$ sitosterol from Chisocheton tomentosus Induces Apoptosis via Dysregulation of Cellular Bax/Bcl-2 Ratio and Cell Cycle Arrest by Downregulating ERK 1/2 Activation.Volume 2012.12-18.

Robinson, T. 1991. Kandungan Senyawa Organik Tumbuhan Tinggi. Diterjemakan oleh Prof. Dr. Kosasih panda winata. Bandung. ITB.

Svehla, G. 1990. Buku Teks Analisis Anorganik Kualitatif Makro dan Semimikro.Edisi kelima. Penerjemah: Setiono, L. dan A.H. Pudjaatmaka. Jakarta: PT Kalman Media Pusaka.

Victor, L. 1980. Antibiotics in LaboratoryTest. The Williams and Wilkins Company, USA.

Wong, C.P., Shimada, M., Nagakura, Y., Nugroho, A.E., Hirasawa, Y., Kaneda, T., Awang, K., Hamid, A., Hadi, A., Mohamad, K., Shio, M., and Morita, H. 2011. Ceramicines E-I, New Limonoids from Chisocheton ceramicus. Chem. Frm Bull. 59:407411.

Yang, M.H., Wang, J.S., Luo, J.G., Wang, X.B., and Kong, L.Y. 2009.Tetranortriterpenoids from ChisochetonPaniculatus. J. Nat. Prod. 72: 20142018. 